\title{
Limited Testing at the Bob Turbeville Site (41WD382), Wood County, Texas
}

Eric A. Schroeder

Unknown

Follow this and additional works at: https://scholarworks.sfasu.edu/ita

Part of the American Material Culture Commons, Archaeological Anthropology Commons, Environmental Studies Commons, Other American Studies Commons, Other Arts and Humanities Commons, Other History of Art, Architecture, and Archaeology Commons, and the United States History Commons

Tell us how this article helped you.

This Article is brought to you for free and open access by the Center for Regional Heritage Research at SFA ScholarWorks. It has been accepted for inclusion in Index of Texas Archaeology: Open Access Gray Literature from the Lone Star State by an authorized editor of SFA ScholarWorks. For more information, please contact cdsscholarworks@sfasu.edu. 


\section{Limited Testing at the Bob Turbeville Site (41WD382), Wood County, Texas \\ Creative Commons License \\ (c) (1) \& 8}

This work is licensed under a Creative Commons Attribution-NonCommercial 4.0 International License 


\section{THE LANGFORD SITE (41SM197), SMITH COUNTY, TEXAS}

\section{Mark Walters}

\section{Introduction}

In 1960 , the Walters family excavated in a house, middens, and a small cemetery at the Langford site (41SM197), a Middle Caddoan period settlement on a high terrace overlooking the Sabine River. The site is about 8 miles west of Gladewater, Texas.

On the basis of artifacts visible on the surface, excavations consisted of trenches to search for occupation areas and features; in addition to the cemetery, several middens were also located at the Langford site. The excavations were uncontrolled, and few field notes were taken, but important information is available on several of the burials in the cemetery as well as some of the grave goods.

\section{Cemetery}

Seven burials were excavated in the Langford site cemetery:

Burial 1: The skeleton was fairly well preserved, with the head at the east end of the burial pit. The hands and feet of the individual were missing. The grave itself was $61 \mathrm{~cm}$ deep. Placed as grave goods with Burial 1 was a single large, plain carinated bowl. A small stemmed arrowpoint was embedded in the groin area.

Burial 2: The only skeletal remains in the $61 \mathrm{~cm}$ deep grave pit were portions of a skull, probably from a child. Grave goods included a small, plain dish and a small Foster Trailed-Incised jar (Figure 1). The jar has broad trailed concentric circles on the body, and two rows of punctations on the rim that divide sets of narrow and interlocking incised lines. The decoration on this Foster Trailed-Incised jars is unlike the eight varieties defined by Schambach and Miller (1984) or Early (1993) in Southwest Arkansas, suggesting it is either an earlier variety of the type (dating before ca. A.D. 1350-1400), or a local, and as yet undefined variety of Foster Trailed-Incised.

Burial 3: A well-preserved skeleton with its head to the east, it was buried in a $97 \mathrm{~cm}$ deep grave. Included as grave goods with Burial 3 were a bowl with a cross-hatched engraved design, a miniature red-slipped and engraved bowl, and a beaker with engraved ladders and snakes (Figure 2).

Burial 4: Only the leg bone of this individual was preserved, but its size suggests that Burial 4 was an adult. Two ceramic vessels were placed with the individual, a plain jar and a plain red-slipped bowl (with a sandy paste).

Burial 5: This individual was likely an adult male, as the skeleton was over $180 \mathrm{~cm}$ in length; the head was at the eastern end of the grave. The skull was deformed or cranially modeled (which is a common prehistoric Caddoan practice [Derrick and Wilson 1997]), and the jaw was reversed. No grave goods were placed with this individual.

Burial 6: This individual also had a cranially modeled skull, again with its head at the eastern end of the grave. A single small, plain ceramic jar was placed to the right of the head. 


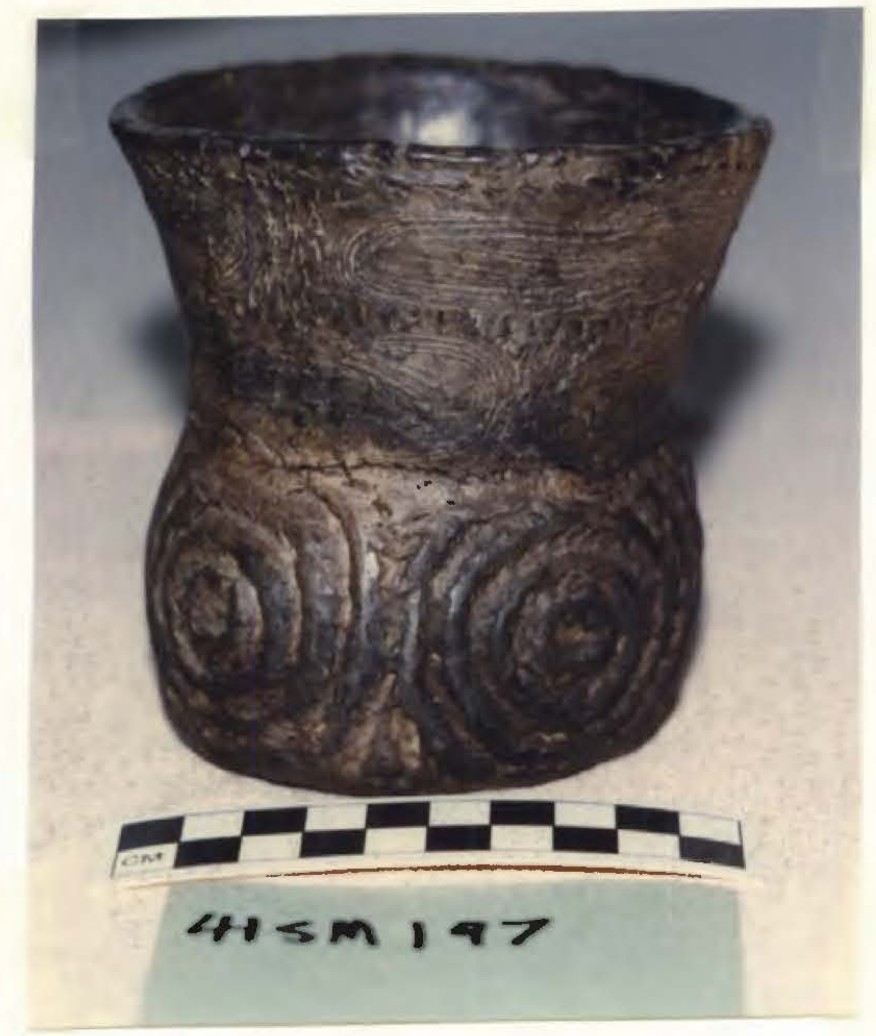

Figure 1. Foster Trailed-Incised vessel from Burial 2.

Burial 7: This was a burial of an adult, and the skeleton was in fair condition. Three ceramic vessels were placed in the grave: a brushedpunctated jar; an engraved-punctated bowl with a folded rim; and a shouldered, plain bowl that contained a lump of kaolin clay. Another lump of kaolin was next to the bowl, and a deer bone was next to the engravedpunctated bowl. A dart point was recovered in the burial fill, along with half of a plain platform pipe (Figure 3). The other half of the pipe was found on the floor of a Caddo house near the cemetery.

\section{Midden}

The only artifact in the collection known to have been found in one of the middens at the site was a large portion of an engraved bottle (Figure 4). The bottle neck is missing, but the globular body has engraved panels filled with diagonal engraved lines, excised pendant triangles below the bottle neck, and a unique set of engraved lines between the panels. A similar engraved bottle has been recovered from Middle Caddoan archeological deposits at 4IUR133 in the proposed Lake Gilmer (Bo Nelson and Tim Perttula, 1996 personal communication).

\section{Summary}

The Langford site appears to represent a single-component Middle Caddoan period settlement, based on the presence of several red-slipped bowls, a brushed-punctated vessel, the occurrence of engraved ladders and panels on bottles and bowls (common Middle Caddoan decorative motifs), and a vessel with engraved snake designs. While not common, vessels with engraved snakes appear to date only to Middle Caddoan period times in the Sabine River and Cypress Creek drainages (Perttula and Cruse 1996; Nelson and Turner 1996; see also this volume). Since few discrete Middle Caddoan period sites 


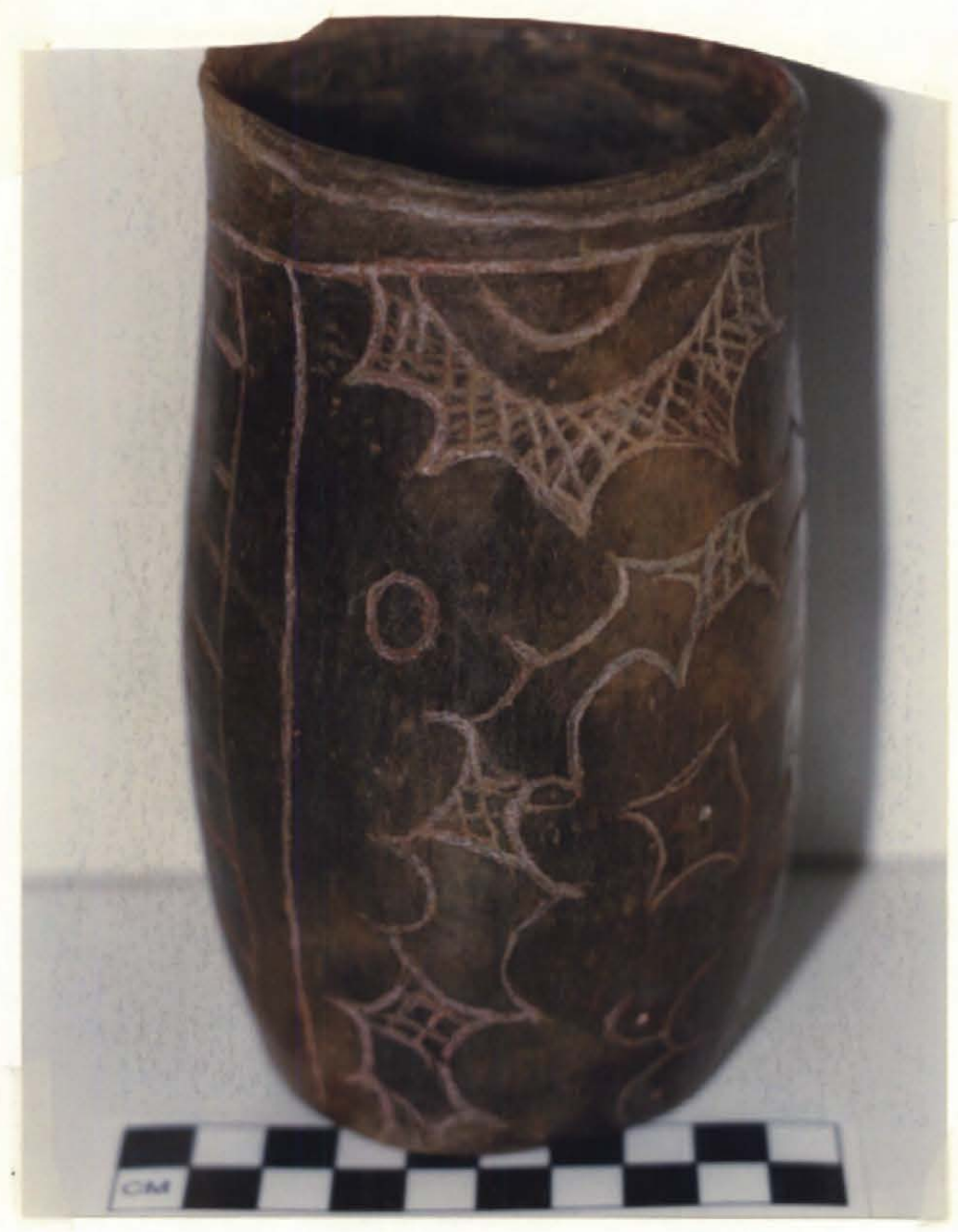

Figure 2. Engraved Beaker from Burial 3.

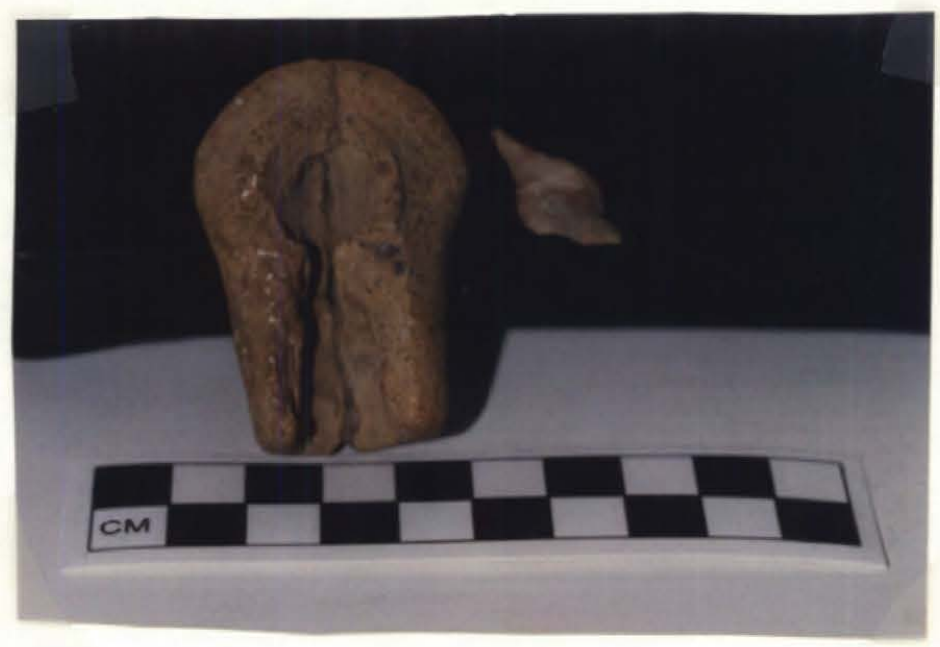

Figure 3. Platform Pipe and Dart Point, Burial 7. 


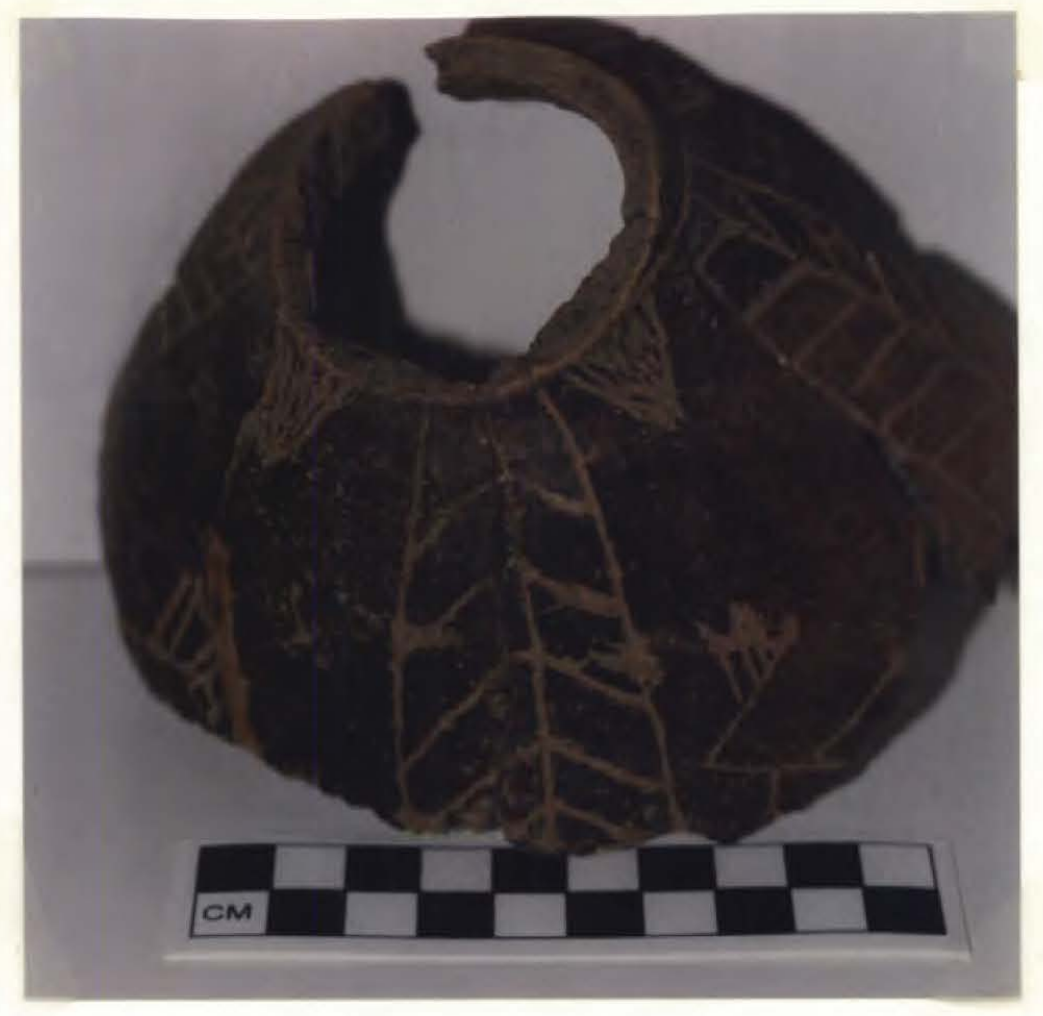

Figure 4. Engraved Bottle from the Langford Site Midden.

have been identified or studied in the Sabine River basin, the Langford site has great potential to contribute important new information on Caddoan lifeways during that period.

\section{References Cited}

Derrick, S. M. and D. E. Wilson

1997 Cranial Modeling as an Ethnic Marker among the Prehistoric Caddo. Bulletin of the Texas Archeological Society 68 , in press.

Early, A. M. (editor)

1993 Caddoan Saltmakers in the Ouachita Valley: The Hardman Site. Research Series No. 43. Arkansas Archeological Survey, Fayetteville.

Nelson, B. and M. Turner

1996 The Middle Caddoan Period in the Big Cypress Creek Drainage Basin. Paper presented at the 1996 Texas Archeological Society meetings, San Antonio.

Perttula, T. K. and J. B. Cruse

1996 The Caddoan Archeology of the Sabine River Basin during the Middle Caddoan Period. Paper presented at the 1996 Texas Archeological Society meetings, San Antonio.

Schambach, F. F. and J. E. Miller

1984 A Description and Analysis of the Ceramics. In Cedar Grove: An Interdisciplinary Investigation of a Late Caddo Farmstead in the Red River Valley, edited by N. L. Trubowitz, pp. 109-170. Research Series No. 23, Arkansas Archeological Survey, Fayetteville. 